\title{
Migration flow management as crime prevention during and after COVID-19
}

\author{
Elena Bagreeva ${ }^{1, *}$ and Angela Mottaeva ${ }^{2,3}$ \\ ${ }^{1}$ Financial University under the Government of the Russian Federation, 49, Leningradsky, 125993, \\ Moscow, Russia \\ ${ }^{2}$ Moscow Region State University, 10A,Radio str., 105005, Moscow, Russia \\ ${ }^{3}$ Moscow State University of Civil Engineering, 26, Yaroslavskoye Shosse, 109377, Moscow, Russia
}

\begin{abstract}
In the context of the COVID - 19 pandemic, the problem of migration flows is becoming more acute and the tasks of managing them are being brought to the fore. The article provides a comparative analysis of the States management decisions during the pandemic concerning migrants, based on the goals of their migration policy. The article analyzes the criminal situation in countries at the beginning of the pandemic period, the structure of illegal actions, as well as the desire of the population to defend their interests. It is argued that institutional management decisions in achieving a balance of interests and needs of various groups of the country's population, including migrants, and the state at the macro and micro levels of social reality will help to avoid a surge in crime
\end{abstract}

\section{Introduction}

Currently, migration processes have become one of the global problems affecting the geopolitical, socio-economic, criminal and sociocultural situation of recipient countries.

The driving force, the main reason for the movement of human flows was numerous military conflicts of the last decade. The situation was complicated by the COVID-19 pandemic. Migrants turned out to be "hostages" in conditions of closed borders of states and loss of earnings due to the suspension of construction projects and small and mediumsized enterprises, where, basically, they worked. The acuteness of the present moment lies not only in the conflict of labor interests with the local population, but also in conflicts in the sociocultural sphere.

Thus, problems associated with migrants arise at the junction of the main provisions of the migration policy of a state and the situation that develops in the labor market during and after the Covid-19 pandemic.

\section{Main part}

These relationships are based on the state migration policy: each country has adopted one of the possible approaches to interacting with migrants.

\footnotetext{
${ }^{*}$ Corresponding author: bagreg@yandex.ru
} 
The first approach was characterized by a strong state interest in migrants of certain professions. And in that case, a system of institutions was built to help solve the problems of this category of migrants.

The second approach of migration policy is implemented when the state does not need additional migration flows, which leads to a fundamentally different algorithm of interaction "society - migrants". And in these countries, migrants sought and found work themselves, often low-paid.

The current situation with COVID-19 "puzzled" both the state and the migrants themselves: "where to live and work next?" The pandemic significantly suspended the livelihoods of countries around the world, leaving most of the world's population unemployed. Small and medium-sized businesses took a devastating blow, where, mainly, migrants were employed.

In this regard, this problem should be considered both from the point of view of state and legal management at the macro level of social reality, and take into account the decision of migrants themselves at the micro level.

Some states close their borders, protecting themselves from the penetration of the coronavirus, and preserving jobs for residents. At the same time, migrants are practically trapped: for example, in response to COVID-19, the Polish leadership made a tough managerial decision, not allowing either to enter or leave Poland (the vast majority of migrants in this country are citizens of Ukraine and Belarus [1]) .

However, the UK, even now with high unemployment caused by restrictive measures to combat the pandemic, is suffering from an acute shortage of agricultural labor and is looking for seasonal workers from other countries, mainly from Romania and Bulgaria..

In addition, despite the coronavirus, German hospitals are in urgent need of certain categories of medical workers for caring for the elderly and are ready even in such conditions to open their doors for them.

US President Donald Trump, in order to save jobs for Americans, signed the Executive Order suspending immigration to the country for a period of 60 days, with possibility to extend it if the situation does not improve [2].

Russia has adopted for itself a different possible management scenario with regard to immigrants. The country's leadership decided that "in the period from March 15 to June 15, 2020, no decisions will be made regarding the deportation, expulsion or undesirability of stay of foreign citizens" [3]. Moreover, they will continue to be able to use visas, work permits, patents, temporary residence permits and residence permits.

Taking into account all the pandemic drama, the employer (with small restrictions) was granted the right to employ foreign citizens without permits [3].

Germany can afford to fully maintain accommodation centers for migrants, half of which are infected with coronavirus [4].

Another example of a way out of this situation has been demonstrated by the leadership Turkey: migrants seeking to cross the border with Greece (many of them were infected with coronavirus) were returned. However, the epidemiological situation in the border cities of the country has recently sharply worsened [5].

Summing up the political decisions taken during the pandemic, it should be recognized that the desire of the EU itself, which claims to develop common recommendations and search for common solutions, is broken by the "sharp stones" of migration policies of individual countries that take into account and determine national interests.

These are examples of solving problems with migrants which are coming from the leadership of countries, i.e. at the macro level of social reality. At the same time, it must be recognized that migrants themselves are ready to realize their ways out of the modern crisis.

Despite the fact that Europe, with its high level of socio-economic development, until recently remained one of the centers where migrants from Libya, Syria, Yemen, 
Iraq, Afghanistan, Somalia, Sudan and other countries flocked ( according to Global Migration Indicators 2018 (UN Migration), 258 million international migrants made up $3.4 \%$ of the World's population), the situation here is beginning to change. So, more than a hundred migrants who arrived earlier from Africa, having met the closed border of Spain, today moved back to Morocco on a rubber boat, paying for that 5.5 thousand euros per person and 300 euros to a guide who knew the safe way. According to the UN International organization for migration, there are still 15,000 people in Spain who also want to return.

In Sweden, the Somali diaspora being disagree with the decision of the country's leadership, which chose not to notice the COVID-19 pandemic, is extremely worried and wants to return to its homeland, but the borders are closed [6].

The migration situation in Europe is so complicated that the European Commission (EC) was forced to consider and adopt on April 16 this year a document regulating the treatment of refugees in a pandemic. It emphasized that: "Any restrictions on asylum return and resettlement must be proportionate, carried out in a non-discriminatory manner." Moreover, the EC insists on the return of migrants to their homeland, despite the pandemic, but recommends that countries "based on national law" apply quarantine for new arrivals [7-9].

On the whole, the European Court holds a similar position, however, it also found it necessary to emphasize that, despite the right of national states to control their borders refugees should be provided with protection.

Such a decision by the European community was inevitable, since the" degree» of migrant problems caused by the pandemic had already reached a critical point: they lose their jobs, they run out of money to even buy food; all borders are closed, turning migrants into hostages. The accumulated tension, and the hopelessness of the situation always gives a rise to aggression and it often results in various forms of disobedience to the established order: from rallies and demonstrations to various kinds of crimes. Unfortunately, this situation cannot be called local typical only for Europe.

In the first month of the pandemic in all parts of the globe, the crime rate in many respects decreased - people had a shock. For example, in Moscow, self-isolation of residents led to a decrease in crime and the number of accidents. In addition, the number of serious crimes (murders and robberies) has decreased. In many countries (Russia, USA, Austria, Germany, Sweden, etc.), due to the large number of cameras installed in cities, there are short-term trends in the reduction of street crime [10-13].

On the one hand, residents needed a certain period of time to adapt and accommodate to the new conditions. On the other hand, a person in a humiliated position, experiencing fear and despair, tends to accumulate discontent, and this "spring" can straighten into a crime.

Such a gracious month of calm in criminal activity has already passed, and today, police, criminologists began to record not only violations of order, but also note the growth of a number of crimes [14].

Of course, these are, first of all, crimes related to illegal border crossing and organization of illegal migration. And, if earlier these offenses were only prescribed in the laws of countries, now they have begun to work. In addition, there has been a sharp increase in the number of frauds using online computer technologies - in Russia it is $48 \%$. In general, cybercrime has flourished, as evidenced by Interpol data. Thus, the structure of the types of crimes committed in the current period is rapidly changing.

At the same time, residents of different countries are openly displeased with insufficient, in their opinion, state attention to their problems, on the one hand, and excessive concern for migrants, on the other. For example, such a policy upsets Germans who have lost their jobs [15]. Therefore, without waiting for the reaction of the state, they 
decide to organize and arm themselves. Not counting on states protection, anti-migrant people's squads of several thousand citizens have already been organized in Dusseldorf for self-defense [10].

In the USA, due to fears of attacks by marauders, arms sales increased by $222 \%$ ! Obviously, not without reason, if we take into account the fact that the police in Salt Lake City appealed to the criminal community to stop all criminal activity until further instructions! [16]. It is obvious that such an "open " appeal by the police - law enforcement agency, to the criminal community could only be made if the destroyed balance in society is recognized and there is a fear of direct clashes with the use of purchased weapons.

\section{Conclusions}

Thus, the intensification of migration processes in the world, and especially in Europe, the change in the population picture after the pandemic period, actualize the study of trends and challenges to the sustainable development of countries. Migrants bring cultural differences to the country, including cultural distance as a determinant of increased tension and distrust on the part of society towards foreign citizens. This concept is based on the idea that different cultures have their own set of traditions, value orientations, behavioral stereotypes, as well as ideas about what is right/allowed and wrong/forbidden/punishable.

The fundamental task is to prove the need for a balanced management of migration processes. Consideration of these processes as a multifactorial phenomenon, causing a change in the content and structure of public institutions in the long term, will help to find a balance of interests and needs of citizens and the state at the macro and micro levels of social reality. A comparative analysis of the trends and challenges of modern migration processes, a generalization of experience based on an analysis of the current situation will allow us to develop effective stabilization measures.

The elimination of the imbalance by improving legal regulation in the implementation of the national migration policy of the state in the name of sustainable development of the country will lead to a reduction in negative challenges leading to crime.

Studying the trends of modern migration processes will help to minimize the challenges and risks of institutional transformation of recipient countries. The coronavirus pandemic, and as a result, the increased geopolitical instability in 2020 , exacerbated the situation and foregrounded the interdisciplinary research of scientists from various countries to develop specific management recommendations of a predictive nature for various spheres of life of States.

\section{References}

1. https://ru.euronews.com/2020/04/05/poland-migrant-workers-report

2. https://www.rbc.ru/politics/23/04/2020/5ea0ca479a794742f2835e02

3. https://rg.ru/2020/04/23/mvd-vspleska-prestuplenij-so-storony-migrantov-nezafiksirovano.html

4. journalistenwatch.com.

5. https://www.kp.ru/daily/27113/4192705/

6. https://rg.ru/2020/04/27/migranty-stali-massovo-vozvrashchatsia-iz-evropy-narodinu.html

7. https://www.pravda.ru/politics/1488581-criminal/

8. https://ria.ru/20200322/1568967827.html?utm_source=yxnews\&utm_medium=deskto p\&utm https://ren.tv/news/v-mire/673091-politsiia-ssha-prosit-prestupnikov-otlozhit- 
dela-iz-za-

koronavirusa?utm_source=yxnews\&utm_medium $=$ desktop\&utm_referrer $=\mathrm{https} \% 3 \mathrm{~A} \%$ 2F\%2Fyandex.ru\%2Fnews

9. referrer=httpshttps://eadaily.com/ru/news/2020/04/22/germaniya-pozvolyaet-seberoskosh-kazhdyy-vtoroy-migrant-zarazhyon-covid-19

10. $7716 /$ svpressa.ru/society/article/24

11. https://ren.tv/news/v-mire/673091-politsiia-ssha-prosit-prestupnikov-otlozhit-dela-iz-

za-

koronavirusa?utm_source $=$ yxnews\&utm_medium $=$ desktop\&utm_referrer $=\mathrm{https} \% 3 \mathrm{~A} \%$ 2F\%2Fyandex.ru\% 2 Fnews

12. E.G. Bagreeva, D.S. Minich, Eurasian bar 6(37), 107-112 (2018)

13. A. Mottaeva, MATEC Web of Conferences 170, 01045 (2018) doi.org/10.1051/matecconf/201817001045

14. N.Y. Ryazanova, A.V. Sharkova, N.E. Lobzhanidze, E.V. Subbotina, O.E. Matyunina, International Journal of Recent Technology and Engineering (2019)

15. N.S. Khoroshavina, A.V. Sharkova, O.N. Vasilyeva, O.V. Borisova, K.O. Sokolov, The classification matrix of sources of new knowledge as a tool for planning a company's innovation (Espacios, 2018)

16. S. Rakhimova, K. Kunanbayeva, L. Goncharenko, A. Pigurin, E3S Web of Conferences 110, 02154 (2019) https://doi.org/10.1051/e3sconf/201911002154

17. K. Kunanbayeva, A. Gorovoy, A. Butyrin, MATEC Web of Conferences 193, 05048 (2018) https://doi.org/10.1051/matecconf/201819305048 